\title{
The Regional Regime Architecture for the Envisioned ASEAN Community Connectivity: Domestic Constraints and Challenges for the Philippines.
}

\author{
Hilton J. Aguja, Ph. D. \\ MSU-Iligan Institute of Technology, Iligan City, Philippines \\ hiltonaguja@yahoo.com, hilton.aguja@g.msuiit.edu.ph
}

Keywords: ASEAN connectivity, international regime, fundamental governance principles, institutional connectivity.

\begin{abstract}
In its continuous effort to fine-tune its institutional ways of doing things to achieve a seamless regulatory framework, the Association of Southeast Asian Nations (ASEAN) has already had two Master Plans on ASEAN Connectivity (MPAC). These documents have been the blueprint for the overall effort of the ASEAN member States to give flesh to the ASEAN motto of 'One vision, One Vision, One Community'. These Master Plans have clearly identified specific areas in the ASEAN's regime making initiatives to 'foster a rule-governed activity' in their mutual interactions. As the first initiative in this regime-making effort, The Ha Noi Declaration on the adoption of the Master Plan on ASEAN Connectivity (MPAC 2010) called for a well-connected ASEAN to put in place an ASEAN Community by 2015. The Declaration speaks of a three pronged approach for the achievement of the envisioned connectivity: Physical connectivity; Institutional connectivity; and People to people connectivity. As a successor document, the Master Plan for ASEAN Connectivity 2025 (MPAC 2025) was adopted on 6 September 2016 in Vientiane, Lao PDR. It focuses on five issues areas, namely 'sustainable infrastructure, digital innovation, seamless logistics, regulatory excellence and people mobility'. To ensure continuity, this new rendition of the Master Plan 'incorporated the remaining initiatives' of its predecessor document. In light of these, the concern of this paper focuses on institutional connectivity that is basically anchored on the political component of the Master Plans. As it stands, various issues currently exist as 'impediments to movement of goods, services and skilled labor across borders'. Needless to say, these issues are policy concerns requiring political decisions that hinge on the political sphere of every member country. It is on this point that this paper derives its relevance. Probing into the fundamental principles undergirding the domestic politics of the Philippines, this paper posits the thesis that the Philippines is not in sync with the ASEAN connectivity initiatives. Thus the paper argues for some fundamental restructuring of the Philippine government to respond expeditiously to the challenges posed by the emerging regional regime architecture in the ASEAN.
\end{abstract}

\section{INTRODUCTION}

The Association of Southeast Asian Nations (ASEAN) is beset with concerns that it must address to streamline its operations to materialize its vision of becoming an ASEAN Community. A major part of this streamlining is the adoption of the Master Plan for ASEAN Connectivity (MPAC). Thus far, two Master Plans have been heralded. The 
first one was the MPAC 2010 which was adopted in Ha Noi on October 2010. It called for a well-connected ASEAN in line with the vision to put in place an ASEAN Community by 2015. The Declaration speaks of a three pronged approach for the achievement of the envisioned connectivity: Physical connectivity, that is, to connect ASEAN through enhanced physical infrastructure development; Institutional connectivity, that is, effective institutions, mechanisms and processes and; People to people connectivity for an empowered people across the region (The ASEAN Secretariat, 2012).

The second ASEAN Master Plan was the MPAC 2025 which was adopted on 6 September 2016 in Vientiane, Lao PDR. It envisions to 'achieve a seamlessly and comprehensively connected and integrated ASEAN that will promote competitiveness, inclusiveness, and a greater sense of community'. The MPAC 2025 specifically focused on 'sustainable infrastructure, digital innovation, seamless logistics, regulatory excellence and people mobility'. To ensure continuity, it 'incorporated the remaining initiatives' of its predecessor document (The ASEAN Secretariat, 2016).

The MPAC set in place a regime to govern areas of activity among ASEAN members. It provides an agreed set of rules and procedures to govern the members' expectations in their dealings and provide uniformity, predictability and stability in their operational transactions.

While the MPACs laid out the rules of the game, it is cognizant of the domestic constraints that act as 'impediments to movement of goods, services and skilled labor across borders' (The ASEAN Secretariat, 2012). These issues are policy concerns requiring political decisions. As such, it shall be the focus of this inquiry through a content analysis of the underlying principles of the MPAC vis-à-vis the principles undergirding the Philippine polity. It is on this point that this paper derives its relevance.

\section{Research Objectives}

The main objective is to track the line of fit between the MPACs and the specific policy trajectory of the Philippines towards ASEAN Connectivity. This paper addresses the following concerns:

1. The fundamental organizing principles of the international regime undergirding the envisioned ASEAN Community.

2. The fundamental organizing principles undergirding the Philippine Polity.

3. The line of fit between these specific organizing principles; and

4. Policy recommendations to address the dissonance, if any. 


\section{The Analytical Framework}

With the effort to create an ASEAN community grounded on a workable ASEAN connectivity architecture, the need to harmonize the organizing principles operative in member states and that of the emerging ASEAN regime architecture becomes a primordial concern. Principles governing the workings of the system acquire a particularly significant role in actual operation. There is therefore a need to ascertain whether the pronounced principles are congruent with each other so as to facilitate the ASEAN community building process. Consequently, the dissonance if any, between the organizing principles undergirding each member state and the emerging ASEAN community must thus be identified for possible bridging through policy intervention and advocacy work. The schematic diagram below is adapted as the research framework.

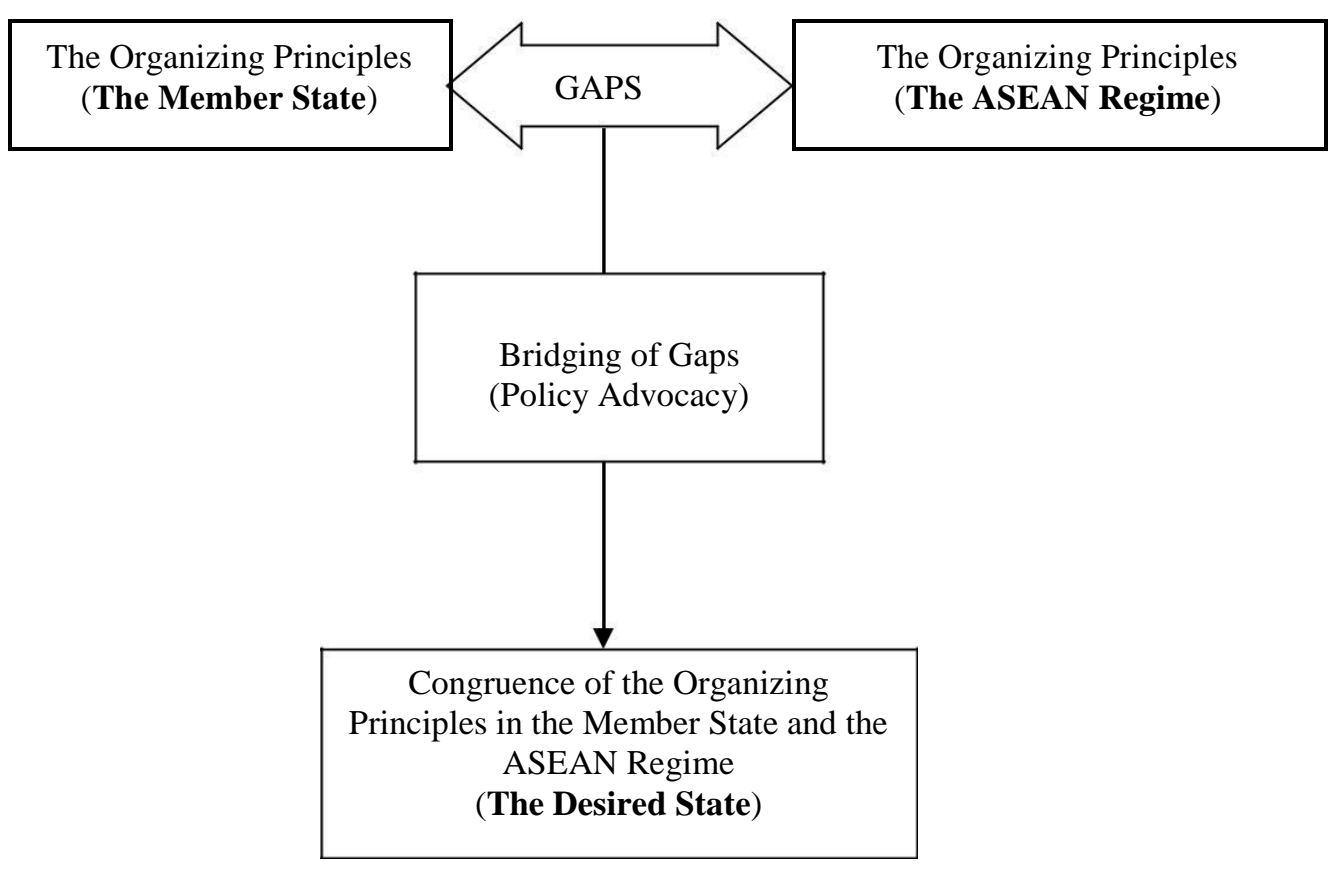

Figure 1: The Schematic Diagram of the Analytical Framework

\section{REVIEW OF RELATED LITERATURE}

The necessity to have rules has been one of the most enduring features of the international system (Bayliss, 2001). These sets principles, norms, rules and decision making procedures around which actors' expectations converge is what Krasner (1983) 
calls an international regime. Thus, the effort to facilitate international relations through the creation of regimes to govern common areas of concern is not entirely a new thing.

\section{The Bretton Woods System: The International Economic Order}

At the end of the Second World War, the United States (US), as the then emerging hegemon established an international economic order (IEO) that was to govern the post war trading relations. It believed that to promote free trade on a global basis, it was necessary to create a transnational agency which would assist nations afflicted with deficits in their international trade accounts. The basic rationale for this is that, a nation in deficit is impelled to control and limit imports. Hence, nations in deficit should be given temporary assistance so that they will not be compelled to do anything that would limit their importation of goods (Lichauco,1976:14).

Toward these ends, the IMF and the World Bank were established in 1944. Though these institutions are international agencies, they are controlled by the US which holds enough voting power to dominate decisions (Constantino, 1977: Hudson 2003).

The immediate tactical function of the IMF is to provide temporary relief to countries suffering from a shortage of international currency due to their transactions in foreign trade. The IMF's twin, the World Bank, discharges a supplemental function to promote the mobility and freedom of investments. The IMF promotes maximum freedom in the international flow of goods and commodities while the World Bank promotes maximum freedom in the international movement of investment capital (Lichauco, 1976:15).

\section{The Underlying Ideology of the Global Economic Order}

The IEO is defined by two elements comprising its ideology. One is the belief that economic relations should be one in which there is the highest degree of free trade in goods and services. This element of the ideology is enshrined in the Charter of the IMF. The second element is the belief in the efficiency of private international capital to undertake the reconstruction and development of the world's economy and, therefore, the necessity to promote foreign investments. This is embodied in the purposes of the World Bank (lichauco, 1976:12).

To concretize the workings of the IEO based on the Bretton Woods principles, the General Agreement on Tariffs and Trade (GATT) was signed in 1947. It was a multilateral agreement regulating international trade. Its purpose was the "substantial reduction of tariffs and other trade barriers and the elimination of preferences, on a reciprocal and mutually advantageous basis." The agreement was designed to provide an international forum that encouraged free trade between member states by regulating and 
reducing tariffs on traded goods and by providing a common mechanism for resolving trade dispute (Zeiler, 1999). Over the years, GATT evolved through several rounds of negotiations. The last and largest GATT round, was the Uruguay Round which lasted from 1986 to 1994 and led to the creation of the World Trade Organization (WTO) in 1995. Whereas GATT had mainly dealt with trade in goods, the WTO and its agreements has expanded GATT coverage and now cover trade in services, and trade in inventions, creations and designs (intellectual property).

\section{FINDINGS AND DISCUSSION}

\section{The ASEAN Community: The Organizing Principles}

The MPAC 2010 bespeaks of a three pronged approach for the achievement of the envisioned connectivity: Physical connectivity, that is, to connect ASEAN through enhanced physical infrastructure development; Institutional connectivity, that is, effective institutions, mechanisms and processes and; People to people connectivity for an empowered people across the region.

Of the three pronged approach for the establishment of a well-connected ASEAN, it is the connectivity on the institutional level is the defining component of the package. It establishes the necessary legal regime to facilitate the whole process of interconnectedness. As to its coverage, the key elements of institutional connectivity involve the following (The ASEAN Secretariat, 2012):

1. Trade liberalization and facilitation

2. Investment and services liberalization and facilitation

3. Mutual recognition agreements /arrangements

4. Cross border procedures

5. Capacity building programmes

The building blocks of ASEAN institutional connectivity is anchored on the principles of liberalization and facilitation of trade, investments and services. These principles are the same operative principles governing the functioning of the General Agreement on Tariff and Trade since 1947 (Irwin, 1995) and subsequently of the Word Trade Organization since 1995 (Zeiler, 1999).

Free trade and freedom of movement of investment capital are the economic ideology that defined the workings of the global economic order engineered after the Second World War through the instrumentalities of the IMF and the World Bank. These two institutions served as the overseer of the global economic order through the establishment 
of the General Agreement on Tariff and Trade and eventually the World Trade organization (WTO) in 1995. These are exactly the same organizing principles followed by the MPAC 2010 and MPAC 2025.

\section{The Organizing Principles of the Philippines Polity}

The Constitution of the Republic of the Philippines is the supreme legal document that defines the parameters within which the government may act legitimately. The Constitution even warns Government officials that "[they] may be removed from office, on impeachment for, and conviction of, culpable violation of the Constitution... (ART $\mathrm{XI}: 2)$.

While the global order and the ASEAN are predicated on the concepts of free trade, openness, internationalization and the like, it is interesting to see what the Philippine Constitution says about these principles.

The Philippines is still encased in its parochialism, reminiscent of the State System of Westphalia. It speaks of an educational system that 'fosters patriotism and nationalism' (Art. II: 17). Its foreign policy is dictated by 'national sovereignty, territorial integrity, national interest, and the right to self- determination' (Art. II: 7). It envisions to develop a 'a self-reliant and independent national economy effectively controlled by Filipinos' (Art. II: 19).

As to its national patrimony, the Constitution, with great detail, prescribes to 'protect Filipino enterprises against unfair foreign competition and trade practices' (Art. XII:1). It further declares that "All...natural resources are owned by the State...The exploration, development and utilization of natural resources shall be under the full control and supervision of the State. The State may directly undertake such activities, or it may enter into co-production, joint venture, or production-sharing agreements with Filipino citizens, or corporations or associations at least sixty per centum of whose capital is owned by such citizens... The State shall protect the nation's marine wealth in its archipelagic waters, territorial sea, and exclusive economic zone, and reserve its use and enjoyment exclusively to Filipino citizens'... (Art. XII: 2).

Further, the Constitution mandates the Congress of the Philippines to "reserve to citizens... or to corporations or associations at least sixty per centum of whose capital is owned by such citizens, or such higher percentage as Congress may prescribe i $\mathrm{n}$ certain areas of investments. The Congress shall enact measures that will encourage the formation and operation of enterprises whose capital is wholly owned by Filipinos ... (Art. XII: 10). 
In the grant of rights, privileges and concessions covering the national economy and patrimony, it gives preference to qualified Filipinos (Art. XII:10). It further emphasized that "...the practice of all professions in the Philippines shall be limited to Filipino citizens, save in cases prescribed by law (Art. XII:14). Further, it requires that "...the ownership and management of mass media shall be limited to citizens of the Philippines, or to corporations, cooperatives or associations, wholly-owned and managed by such citizens... Only Filipino citizens or corporations or associations at least seventy per centum of the capital of which is owned by such citizens shall be allowed to engage in the advertising industry and... all the executive and managing officers of such entities must be citizens...' (Art. XVI:11).

Very clearly, the Philippine Constitution is grounded on the principles that are not attuned to the organizing principles of the ASEAN regime. This dissonance is an urgent matter that must be looked into; otherwise, the contradictions in principles would clash making it difficult to create a regime architecture that would serve as basis for governance in the ASEAN community.

\section{Prospects for Constitutional Revision in the Philippines}

The Pulse Asia survey in December 2001 observed that majority of the people (52\%) favored changing the Constitution (Abueva, 2002). Another survey conducted in May 2006 indicated that $64 \%$ of Filipinos favor charter change (Jurado, 2006). The time is ripe to search for an alternative mode of governance in the country. The predisposition of the present administration of President Rodrigo Duterte is another boost for charter change.

Having dissonance in the organizing principles of the Philippine political economy and the emerging ASEAN political and economic architecture, some degree of openness must be injected in the very nationalistic provisions of the Constitution. As it currently stands, no matter how willing the Philippine government may be in fine-tuning its acts towards ASEAN connectivity, it is always incapacitated by its Constitution.

On the political front, this dilemma is magnified by the presidential system of government in the country. With its separation of powers and functions coupled with coequality among the three branches, the government apparatus is prone to deadlocks particularly if different political parties are in control of the separate branches of government.

Incidentally, when the present Constitution was drafted, those who argued for a parliamentary set up lost by only one vote in favor of a presidential structure (Abueva, 2002). Also, by a margin of one vote, the Senate was restored the Senate thereby 
returning to bicameralism in law-making (Nolledo, 1987). Also, the Philippine Constitution is 'one of the longest in the world... [with] infirmity arising from more than fifty of its provisions, including major ones, requiring enabling laws by Congress before they can be implemented' (Casiple, 2002). These loopholes subject the Constitution to the prevailing political equation in the legislative department.

Given its history, it is not surprising that among the major arguments for changing the Constitution hinges on the horizontal shift from presidential to parliamentary and vertical structural shift from unitary to a federal set up. This trend, viewed from a larger perspective, notes one writer, is simply in keeping with the overall tide of democratization that has swept the world since the collapse of the former Soviet Union. In this rapid modernizing time where democratization is a common feature, only two forms of government are relevant: Presidentialism and Parliamentarism (Sosmeňa, 2001).

\section{Changing the Fundamental Government Structure}

As to the appropriate political structure to be set in place, Dr. Jose V. Abueva (2002) of the University of the Philippines summed it all when he said: "Political Scientists have concluded that democracies with a parliamentary system are more stable and productive". For their part, Juan Linz and Anuro Valenzuela (1994) observed that South America, which is the continent of presidentialism, rarely, if ever, produced lasting political democracy. They further noted that the most stable democracies of Europe have been parliamentary regimes while most countries with presidential constitutions have been unstable democracies or authoritarian regimes. Professor Fred Riggs of the University of Hawaii also joined the discourse with the observation that the presidential system has not succeeded anywhere except the United States (cited in Sosmeňa, 2001).

Corroborating all these generalizations about the failures of the presidential system, the economic performance of Southeast Asian countries is also very telling. The table shows fast growing Asian economies noticeably have parliamentary governments while the slow performing economies have presidential governments. 
Table 1

30 YEAR AVERAGE GDP GROWTH RATES OF SELECTED ASIAN COUNTRIES AND THEIR FORM OF GOVERNMENT

\begin{tabular}{|l|l|l|}
\hline \multicolumn{1}{|c|}{ COUNTRY } & RATE & FORM OF GOVERNMENT \\
\hline KOREA & $6.4 \%$ & PARLIAMENTARY \\
\hline SINGAPORE & $6.3 \%$ & PARLIAMENTARY \\
\hline MALAYSIA & $5.9 \%$ & PARLIAMENTARY \\
\hline THAILAND & $5.7 \%$ & PARLIAMENTARY \\
\hline INDONESIA & $5.3 \%$ & PRESIDENTIAL \\
\hline PHILIPPINES & $3.1 \%$ & PRESIDENTIAL \\
\hline
\end{tabular}

The Philippine rate of growth is half the rate of other Asian countries

Source : The Wallace Report (2004). http://www.dataphil.com/wallacereport.htm

While the above table shows the link between economic growth and political structures, the table that follows shows the proneness to corruption of certain political structures. It does not come as a surprise to see that the presidential set up has failed to bring economic growth in countries that has adopted it because it is also the political system that has brought forth the most number of very corrupt leaders in the world.

Table 2: TOP TEN CORRUPT LEADERS

\begin{tabular}{|c|c|c|}
\hline 1. MOHAMED SUHARTO & PRESIDENT, INDONESIA (1967-1998) & $\$ 15-35$ BILLION \\
\hline 2. FERDINAND MARCOS & PRESIDENT, PHILIPPINES (1965-1986) & $\$ 5-10$ BILLION \\
\hline 3. MOBUTU SESE SEKO & PRESIDENT, ZAIRE (1965-1997) & $\$ 5$ BILLION \\
\hline 4. SANI ABACHA & PRESIDENT, NIGERIA (1993-1998) & $\$ 2-3$ BILLION \\
\hline 5. SLOBODAN MILOSEVIC & PRESIDENT, SERBIA (1989-2000) & \$1 BILLION \\
\hline 6. JEAN DUVALIER & PRESIDENT, HAITI (1971-1986) & $\$ 300-800$ MILLION \\
\hline 7. ALBERTO FUJIMORI & PRESIDENT, PERU (1990-2000) & $\$ 600$ MILLION \\
\hline 8. PAVLO LAZARENKO & PRIME MINISTER, UKRAINE (1996-1997) & $\$ 114-200$ MILLION \\
\hline 9. ARNOLDO ALEMAN & PRESIDENT, NICARAGUA (1997-2002) & $\$ 100$ MILLION \\
\hline 10. JOSEPH ESTRADA & PRESIDENT, PHILIPPINES (1998-2001) & $\$ 78-80$ MILLION \\
\hline
\end{tabular}

No other country in Asia can boast of having two of its leaders in the top ten corrupt leaders. Global Corruption Report 2004. http://www.dataphil.com/wallacereport.htm 
If these tabulated statistics is telling something, former Prime Minister Lee Kuan Yew of Singapore has become its spokesman. He said: "The Philippines has chosen the most difficult political system to operate, with its checks and balances and gridlocks between the executive and the legislature. If this were the system chosen by South Korea, Hong Kong, Taiwan, or we ourselves, we would not have attained the status that we have now" (cited in Enrile, 2002). One can no longer overemphasize the necessity of changing the structure of government in the Philippines.

The proneness to gridlocks between the executive and the legislattive in a presidential system is not conducive with the emerging ASEAN regional architecture. In parliamentary systems, the decision of the parliament binds the entire government, as there is a fusion of the executive and legislative assemblies. In contrast, the presidential set up in the Philippines can keep hostage the other branches on the grounds of coequality and separation of powers. If there is disagreement emanating from both the executive and the legislative branches, the likelihood of resolution is remote given that the two branches are technically separate and equal and more so if political parties of different persuasions are in control of the other branches. This is a structural dilemma that must also be addressed as the country revisits its fundamental law.

\section{CONCLUSIONS AND RECOMMENDATIONS}

After surveying the ideological landscape that undergirds the workings of the Philippine polity and that of the envisioned ASEAN Community, the following conclusions are warranted:

1. The ASEAN Community is envisioned to operate on the basis of the principles governing the international economic order that has been in effect since the end of the Second World War. These principles are anchored on the free flow of goods, free flow of services, free flow of investments and free flow of skilled labor and human development to facilitate world trade.

2. The Philippine polity is organized on the basis of principles that are not attuned with the principles of free trade and free movement of investment capital. It remains parochial as its Constitution prescribes protectionist measures limiting foreign participation in the economy by reserving huge areas of the economy for Filipino citizens. This does not augur well with the emerging ASEAN economic architecture.

3. The organizing principles underlying the ASEAN Community and the operating principles governing the Philippines congruent.

4. By way of recommendation, the Philippines is urged to break free of its parochial outlook and inject openness in the economic provisions in its Constitution so as to enable the government to respond to the opportunities and challenges posed by the emerging ASEAN community. Moreover, it is recommended that the structure of government be horizontally structured to shift from presidential to parliamentary and vertically structured to shift from unitary to a federal set up. These structural changes are proposed to make the Philippine 
government more responsive to the challenges borne by the sweeping changes in the global arena.

\section{References}

Abueva, Jose V. (2002). Towards a Federal Republic of the Philippines with a Parliamentary Government by 2010. Marikina: Center for Social Policy and Governance.

ASEAN Secretariat (2012). The Master Plan on ASEAN Connectivity 2010. Community Relations Division, Jakarta, Indonesia.

ASEAN Secretariat (2016). The Master Plan on ASEAN Connectivity 2025. Community Relations Division, Jakarta, Indonesia.

Bayliss, John and Steve Smith (2001). The Globalization of World Politics. New York: Oxford University Press.

Bernas, Joaquin G., S.J.(1993). "To Amend or Not to Amend But How?" The Manila Chronicle, 19 May 1993.

Casiple, Ramon C. (2002). Imperative for Constitutional Reform. A Paper Presented at the All-Parties Conference Technical Working Group, 27 April 2002, ACCEED Center, Asian Institute of Management.

Constantino, Renato. (1977). Insight and Foresight: Selected Excerpts annotated by Luis Mauricio. Quezon City: Foundations for Nationalist Studies.

Coronel, Shiela S., Yvonne T. Chua, Luz Rimban and Booma B. Cruz. (2004). The Rulemakers: How the Wealthy and Well-Born Dominate Congress. Quezon City: Philippine Center for Investigative Journalism.

Enrile, Juan Ponce. (2002). The Presidential System Has Failed Us, Let Us Change It. A paper delivered before the Laban ng Demokratikong Pilipino (LDP) Legislative Agenda Workshop held at the Holiday Inn, Mimosa, Clark, Pampanga. July 19, 2002.

Hudson, Michael. (2003). Super Imperialism: The Origin and Fundamentals of U.S. World Dominance, 2nd ed. London and Sterling, VA: Pluto Press.

Irwin, Douglas A. (1995). "The GATT in Historical Perspective," American Economic Review Vol. 85, No. 2. 
Jurado, Emil P. (2006). "Senate Becoming Irrelevant", Philippine Graphic, Vol.17 No. 5, July 102006.

Krasner, Stephen (1983). International Regimes. Ithaca, New York: Cornell University Press.

Lichauco, Alejandro. (1976).The International Economic Order and the Philippine Experience, a paper prepared for a convocation of the student body of St. Scholastica College, September 3, 1976, Manila Philippines.

Linz, Juan and Valenzuela, Anuro, eds. (1994). The Failures of the Presidential Democracy: Comparative Perspectives. Vols. I \& II. Baltimore: Johns Hopkins University Press.

Nolledo Jose N. (1987). The Constitution of the Republic of the Philippines Explained. First Edition. Manila: National Bookstore.

Sosmeňa, Gaudioso Jr. C. (2001). Philippine Federal Republic: Progression or Retrogression? A paper Presented to the Strategic Studies Group, National Defense College of the Philippines (NDCP), 29 May 2001.

Villacorta, Wilfredo V. (2002). Fundamental Issues on Changing the Constitution. A Paper Presented at the National Political Summit, Manila Hotel, 3 May 2002.

Zeiler, Thomas W. (1999) Free Trade, Free World: The Advent of GATT 
Advances in Social Science, Education and Humanities Research, volume 191 
Advances in Social Science, Education and Humanities Research, volume 191 